\title{
Tufted folikülit: Bir olgu sunumu
}

\section{Tufted hair folliculitis: A case report}

\section{Illknur Balta, Murat Baykır*, Șahande Nur Yüksel**, Müzeyyen Astarcı***, Alev Eken**, Meral Ekșioğlu*}

\author{
S.B. Etlik İhtisas Eğitim ve Araștırma Hastanesi, Deri ve Zührevi Hastalıklar Kliniği, Ankara, Türkiye \\ *S.B. Ankara Eğitim ve Araștırma Hastanesi, Deri ve Zührevi Hastalıklar Kliniği ve ***Patoloji Kliniği Ankara, Türkiye \\ **Alederm Kozmetik Deri ve Zührevi Hastalıklar Merkezi, Ankara, Türkiye
}

\section{Özet}

Tufted folikülit (TF), saçlı derinin, tek bir folikül ağzından çok sayıda kılın çıkısıı ve skatrisyel alopesi ile karakterize, kronik, ilerleyici, inflamatuvar bir hastalı̆ı̆ıı. On dört yaşında, kız çocuk, on yıldır devam eden saçı deride akıntılı, kaşıntılı, iltihabi yaralar şikayetiyle polikliniğimize başvurdu. Dermatolojik muayenede, saçılı deride paryeto-oksipital bölgede, $15 \times 25 \mathrm{~cm}$ boyutlarında, sklerotik plak zemininde, her bir dilate folikül ağzından 10-15 adet normal saçın dışarı çıktığı gözlendi. Histopatolojik inceleme ile TF tanısı kondu. Hastaya, 3 hafta boyunca verilen $600 \mathrm{mg} / \mathrm{gün}$ rifampisin, $1500 \mathrm{mg} /$ gün sefaleksin, $1000 \mathrm{mg} /$ gün vitamin C tedavisi etkili olmadı. Sonrasında 0,5 mg/kg/gün isotretinoin 6 ay süreyle verildi. Bu tedavi ile saçlı derideki inflamasyon ve eksudasyon azalırken, kümeleşmiş saçlar sebat ediyordu. TF tanısı konan bu olgu nadir görülmesi nedeniyle sunulmakta ve tedavisindeki güçlükler üzerinde durulmaktadır. (Türkderm 2013; 47: 120-2)

Anahtar Kelimeler: Tufted folikülit, isotretinoin, rifampisin, tedavi

\section{Summary}

Tufted hair folliculitis (THF) is a recurrent and progressive folliculitis of the scalp that resolves with irregular areas of scarring alopecia within which numerous hair tufts emerge from dilated follicular openings. A 14-year-old female presented with pruritic, inflammatory and exudating wounds on the scalp which appeared ten years ago. Dermatological examination revealed tufts of 10 to 15 apparently normal hair shafts in a sclerotic plaque measuring $15 \times 25 \mathrm{~cm}$ on the parieto-occipital region of the scalp that emerge through dilated follicular openings. The patient was diagnosed by histopathological examination as having THF. Oral rifampicin $600 \mathrm{mg} /$ day, cephalexin $1500 \mathrm{mg} /$ day and vitamin C $1000 \mathrm{mg} /$ day for 3 weeks were not effective, then, he was treated with isotretinoin $0.6 \mathrm{mg} / \mathrm{kg} /$ day for six months. The inflammation and exudation decreased by this treatment while hair tufting was persisting. We report this case since THF is rarely encountered disease and is difficult to be treated. (Turkderm 2013; 47: 120-2)

Key Words: Tufted hair folliculitis, isotretinoin, rifampin, therapy

\section{Giriş}

Tufted folikülit (TF); tek bir folikül ağzından çok sayıda kılın çıkışı ve skatrisyel alopesi ile karakterize, saçlı derinin kronik, inflamatuvar ve ilerleyici bir hastalığıdır. Etyopatogenezi tam olarak bilinmemektedir. Nevoid anomaliler, infeksiyöz etyoloji ve telojen saçların retansiyonunun sorumlu olabileceği düşünüldüğü gibi, saçlı derinin çeşitli inflamatuvar hastalıklarına sekonder bir fenomen olabileceği de ileri sürülmektedir. Bazı yazarlar ise TF'nin folikülitis dekalvansın bir varyantı olduğunu ileri sürmüşlerdir1.

Burada tipik klinik ve histopatolojik özellikleri ile TF tanısı konan bir olgu sunulmakta ve TF etyopatogenezi tartışılmaktadır.

Yazışma Adresi/Address for Correspondence: Dr. İlknur Balta, S.B. Etlik Ihtisas Eğitim ve Araştırma Hastanesi, Deri ve Zührevi Hastalıklar Kliniği, Ankara, Türkiye Tel.: +903125953242 E-posta: drilknurderm@yahoo.com Geliş Tarihi/Received: 06.04.2011 Kabul Tarihi/Accepted: 01.06.2011 


\section{Olgu}

On dört yaşında, kız çocuk, on yıldır devam eden saçıı deride akıntılı, kaşıntılı, iltihabi yaralar şikayetiyle polikliniğimize başvurdu. Saçlı deriye herhangi bir travma öyküsü yoktu. Başka bir hastalığı bulunmuyordu. Ebeveynlerinde ve kardeşlerinde benzer şikayeti olan kimse yoktu. Dermatolojik muayenede, saçlı deride paryeto-oksipital bölgede 15×25 cm boyutlarındaki, parlak görünümlü, sklerotik zemin üzerinde, her bir dilate folikül ağzından 10-15 adet normal saçın dışarı çıktığ gözlendi (Resim 1a, b). Folikül etrafına basınç uygulamakla pürülan akıntı çıktığı izlendi. Fizik muayenede herhangi bir patoloji saptanmadı. Laboratuvar tetkiklerinde serum biyokimyası, tam kan sayımı, ANA, Anti-ds DNA, sifiliz serolojisi, normal sınırlar içerisindeydi. Eritrosit sedimantasyon hızı 36 mm/saat, total lgE $489 \mathrm{lU} / \mathrm{mL}$ olarak yüksekti. Pürülan akıntının kültüründe Staphylococcus aureus üredi. Mantar kültüründe üreme olmadı. Lezyonlu bölgeden alınan biyopsinin histopatolojik incelemesinde foliküler açıklığın derin invajinasyon göstererek, içerisinden birden fazla sayıda kılın çıktığı saptandı. Ayrıca kıl folikülü çevresinde izlenen belirgin nötrofil, lenfosit ve plazma hücrelerinden zengin, mikst tipte iltihabi hücre infiltrasyonunun, kıl folikül yapısını bozduğu tespit edildi (Resim 2a, b). Hastaya bu klinik ve histopatolojik bulgularla TF tanısı kondu. Üç hafta boyunca verilen 600

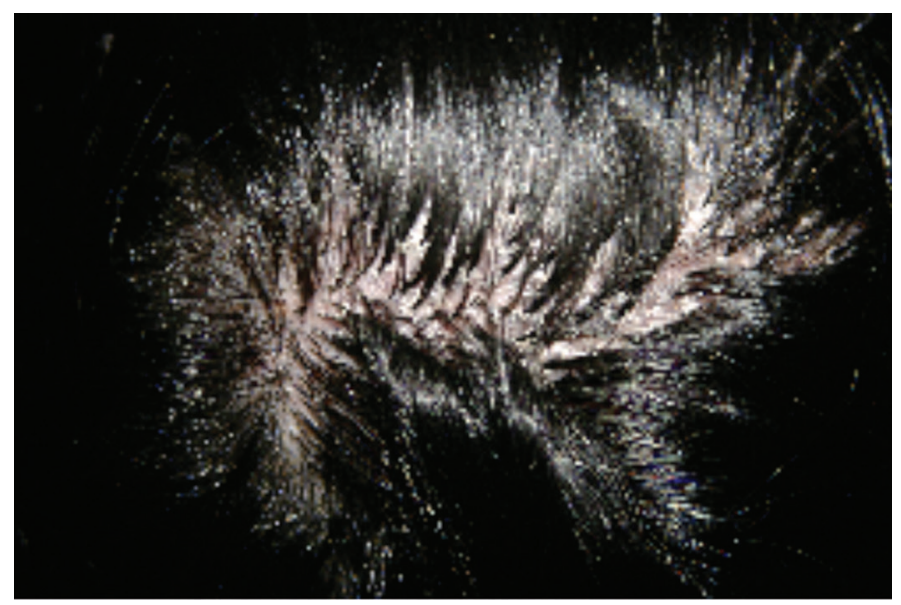

Resim 1 a) Parlak görünümlü, sklerotik zeminde tek bir foliküler ağızdan ortaya çıkan kümeleşmiş saçlar

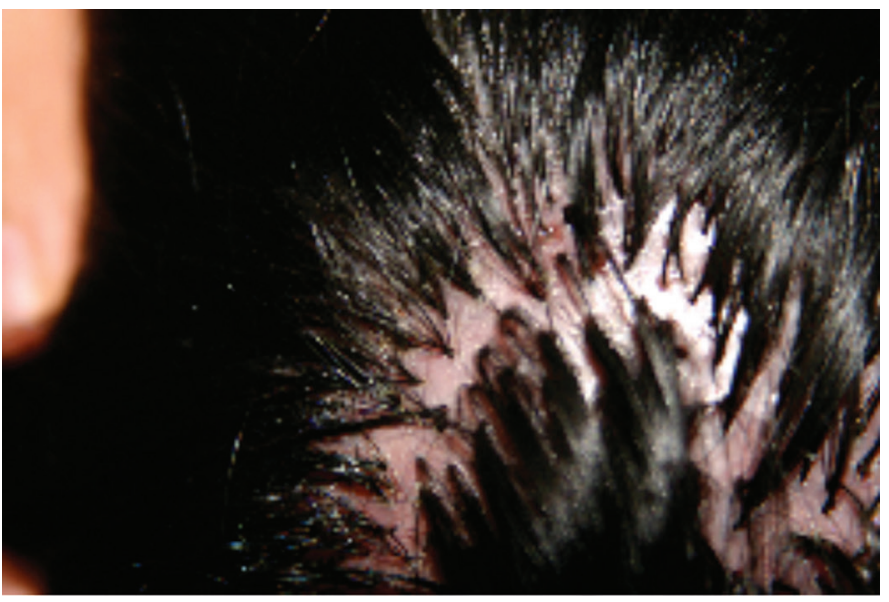

Resim 1 b) Aynı lezyonun yakından görünümü mg/gün rifampisin, 1500 mg/gün sefaleksin, 1000 mg/gün vitamin C tedavisi etkili olmadı. Sonrasında $0,5 \mathrm{mg} / \mathrm{kg} /$ gün isotretinoin 6 ay süreyle verildi. Bu tedavi ile saçlı derideki inflamasyon ve eksudasyon azalırken, kümeleşmiş saçlar sebat ediyordu. Hasta halen takip edilmektedir.

\section{Tartışma}

TF ilk olarak 1978'de Smith ve Sanderson tarafından tanımlanmıştır. Etyopatogenezi tam olarak bilinmemektedir. Nevoid anomaliler, infeksiyöz etyoloji ve telojen saçların retansiyonunun sorumlu olabileceği düşünüldüğü gibi saçlı derinin çeşitli inflamatuvar hastalıklarına sekonder bir fenomen olabileceği de ileri sürülmektedir². Tong ve Baden'in ileri sürdüğü TF patogenezindeki nevoid anomali teorisi son zamanlarda desteklenmemektedir. Çünkü önceden tutulmayan alanlarda da zamanla yeni lezyonlar ortaya çıkabilmektedir ${ }^{3}$. Çoğu olguda Staphylococcus aureus izole edilmiştir. Staphylococcus aureus'un bu hastalığın patogenezinde önemli bir rol oynadığı

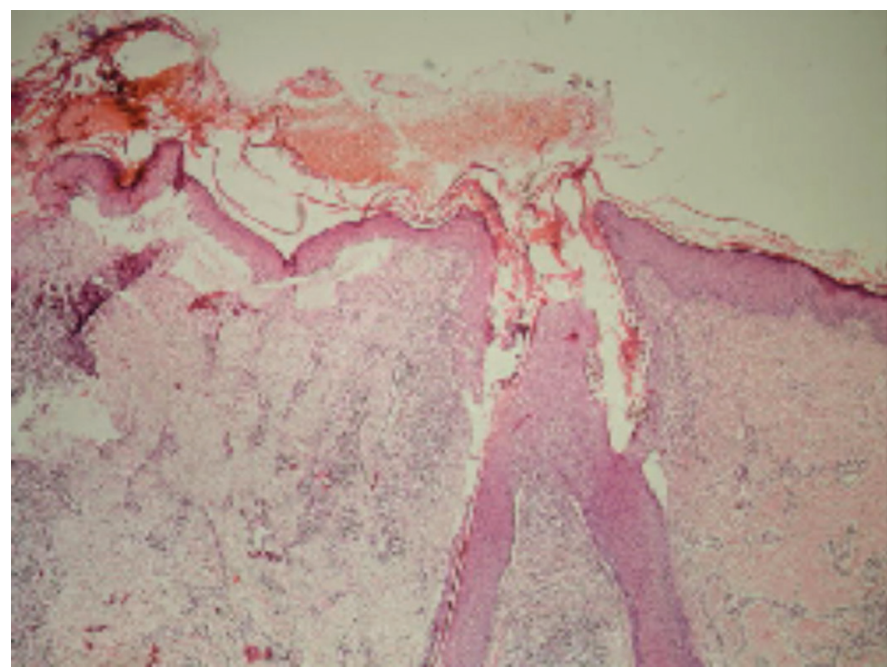

Resim 2 a) íki ayrı folikülün üst dermiste birleşerek, ortak bir dilate foliküler ağızla dışarı açılması (H\&E)

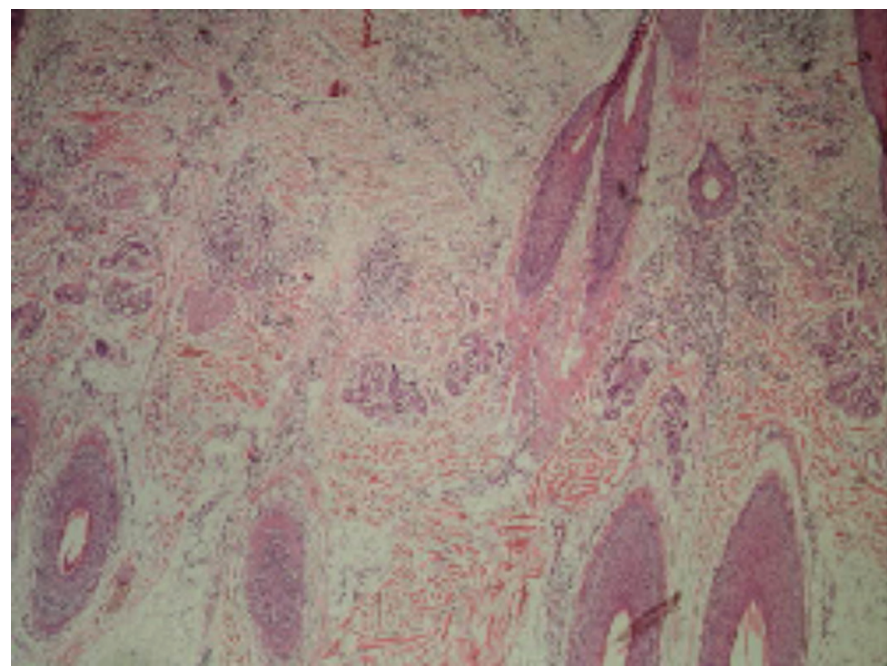

Resim 2 b) Derin perifoliküler alanda intakt folikül papillaları (H\&E) 
düşünülmektedir. Staphylococcus aureus bazı enzim ve toksinleri üreterek patojenik etki gösteriyor olabilir4 ${ }^{4}$ Bazı yazarlar TF'nin kronik ve relaps gösteren seyrinin Staphylococcus aureus gibi bir patojene karşı konağın yetersiz immün yanıtı sonucu olabileceğini ileri sürmüşlerdir2. Powel ve arkadaşları, 8'inde hastalığın seyri sırasında TF gelişen 18 folikülitis dekalvanslı hastada yaptıkları immünohistokimyasal incelemede, CD4/CD8 ve T hücre/B hücre oranının normal olduğunu saptayarak, ortak bir patojene karşı, konağın anormal immün yanıtını gösterecek herhangi bir kanıt elde etmediklerini bildirmişlerdir5. TF patogenezindeki bir diğer teori, telojen saçların retansiyonu olmakla birlikte, bazı yazarlar TF'li hastalarda yaptıkları histopatolojik incelemede kümeleşmiş saçların çoğunun anajen fazda olduğunu saptamışlardır ${ }^{4}$. Pujol ve arkadaşları TF'nin saçlı derinin dissekan selüliti, akne keloidalis veya folikülitis dekalvans gibi saçlı derinin inflamatuvar hastalıklarına sekonder bir fenomen olduğunu ve spesifik bir hastalık olmadığını düşünmüşlerdir6. Literatürde saçlı deride pemfigus vulgaris lezyonlarını takiben yada travmaya sekonder gelişen TF olguları bildirilmiştir7,8,9. Annessi ve arkadaşları ise TF'nin folikülitis dekalvansın bir varyantı olduğunu ileri sürmüşlerdir ${ }^{1}$.

TF her iki cinste görülür ve erkek/kadın oranı 2,7/1'dir10. Başlangıç yaşı genellikle 19 ile 68 yaş arasında değişir. Lezyonlar sıklıkla paryetal ve oksipital bölgede yerleşir. TF, saçlı deride yavaşça genişleme gösteren bir veya daha fazla inflamatuvar ve eksudatif plakla başlar. Bunlar her bir folikül ağzından 5-20 adet normal kılın çıktığı eritemli, parlak görünümlü, sklerotik deri ve yer yer skatrisyel alopesik alanlar ile sonuçlanır. Folikül çevresine basınç uygulamakla pürülan akıntı çıktığı gözlenir. Bu pürülan akıntıdan genellikle Staphylococcus aureus izole edilir2,9. Histopatolojik incelemede, tek bir foliküler infundibulumdan çok sayıda kııın ortaya çıktığı, üst ve orta dermiste, sıklıkla yabancı cisim dev hücreleri ve histiyositlerden oluşan granülom formasyonunun da eşlik ettiği, nötrofil, lenfosit ve plazma hücrelerinden oluşan infiltrat izlenir. Üst dermiste komşu folikül duvarının yapısının bozulduğu, fakat derin perifoliküler alanda folikül papillalarının intakt olduğu saptanır8. Ayırıcı tanısı, multipl saç kümeleri ile karakterize durumlar ve saçlı derinin etyolojisi bilinmeyen, skatrisyel alopesiye neden olan inflamatuvar hastalıkları ile yapılmalıdır. TF, pili multigemini ve trikostazis spinülozadan tipik klinik görünümü ile ayırt edilebilir. Folikülitis dekalvans, saçlı derinin atrofik ve alopesik alanlar, bu alanların periferinde bulunan foliküler püstüller ile seyreden kronik, progresif, inflamatuvar bir hastalığıdır. Saçlı derinin dissekan selüliti, fluktuan olabilen multipl nodüller ve içerisinden pü gelen sinüsler ile karakterize bir hastalıktır. Genellikle yama şeklinde saç kaybı görülür. Folikülitis dekalvans, saçlı derinin dissekan selüliti ve TF; klinik, bakteriyolojik ve histopatolojik olarak benzer özellikler gösterir. Ancak bu hastalıklar arasındaki ilişki tam olarak bilinmemektedir. Püstül ve nodüller TF'de görülmezken, folikülitis dekalvans ve saçlı derinin dissekan selülitinde, kümeleşmiş saçlar görülmez².

Progresif skatrisyel alopesiye neden olan TF'nin tedavisi oldukça zordur. Topikal antiseptik tedavilerin ve oral antibiyotiklerin (fluoksasilin, eritromisin, tetrasiklin ve doksisiklin) inflamatuvar komponenti iyileştirdiği, fakat kümeleşmiş saçları azaltmadığı gözlenmiştir². Literatürde rifampisin ile tedavi edilen hastalarda eritemin azaldığı, papülopüstüler lezyonların kaybolduğu, fakat kümeleşmiş saçlar ve sikatrisyel alopesik alanlarda belirgin bir değişiklik gözlenmediği bildirilmiştir11,12. Rifampisin stafilokoklar üzerine oldukça etkili bir ajandır. T hücrelerin fonksiyonunu ve antijene duyarlanmış lenfositlerin transformasyonunu suprese ederek hücresel immüniteyi etkiler Rifampisine hızlı rezistans gelişir ve bu nedenle bu ilacın tek başına kullanımı önerilmez. Siprofloksasin, klaritromisin, klindamisin ve doksisiklin ile kombine edilebilir. Powell ve arkadaşları, hastalığın seyrinde 8'inde TF gelişen, 18 folikülitis dekalvanslı hastayı oral rifampisin ve klindamisin kombinasyonu ile tedavi etmişlerdir. $600 \mathrm{mg} /$ gün rifampisin ve $600 \mathrm{mg} /$ gün klindamisin 10 hafta boyunca kullanılmış, 18 hastanın 15'inde iyileşme gözlenmiş, bir veya birkaç kür tedaviden sonra relaps gözlenmemiştir ${ }^{5}$. Pujol ve arkadaşları TF'li bir hastada $1 \mathrm{mg} / \mathrm{kg} /$ gün dozunda isotretinoini 20 hafta kullanmışlar. Tedavi sırasında lezyonların asemptomatik hale geldiğini, fakat tedavi sonlandırıldıktan sonra relaps gözlendiğini bildirmişlerdir2 ${ }^{2}$ Ekmekçi ve arkadaşları TF'li bir hastada $1 \mathrm{mg} / \mathrm{kg} /$ gün prednizolon iki ay, $1 \mathrm{mg} /$ $\mathrm{kg} /$ gün isotretinoin iki ay, $20 \mathrm{mg} /$ hafta metotreksat üç ay boyunca sırasıyla kullandıklarını, fakat lezyonlarda belirgin bir değişiklik olmadığını bildirmişlerdir10.

Bildirilen olguya tipik klinik ve histopatolojik özellikleri nedeniyle TF tanısı kondu. 600 mg/gün rifampisin, 1500 mg/gün sefaleksin, 1000 mg/gün vitamin C başlandı. Üç hafta sonra lezyonlarda belirgin bir değişiklik olmadı ve tedavi sonlandıııldı. Sonrasında $0,5 \mathrm{mg} / \mathrm{kg} / \mathrm{gün}$ isotretinoin 6 ay süreyle verildi. Bu tedavi ile saçlı derideki inflamasyon ve eksudasyon azalırken, kümeleşmiş saçlar sebat ediyordu.

Tipik klinik ve histopatolojik özellikleri ile TF tanısı konan bu olgu nadir görülmesi nedeniyle sunulmakta, TF etyopatogenezi tartışılarak, tedavisindeki güçlükler üzerinde durulmaktadır.

\section{Kaynaklar}

1. Annessi G. Tufted folliculitis of the scalp: a distinctive clinicohistological variant of folliculitis decalvans. Br J Dermatol 1998;138:799-805.

2. Pujol RM, Matias-Guíu X, Garcia-Patos V, de Moragas JM. Tufted-hair folliculitis. Clin Exp Dermatol 1991;16:199-201.

3. Tong AK, Baden HP. Tufted hair folliculitis. J Am Acad Dermatol 1989;5:1096-9.

4. Luelmo-Aguilar J, Gonzalez-Castro U, Castells-Rodellas A. Tufted hair folliculitis. A study of four cases. Br J Dermatol 1993;128:454-7.

5. Powell JJ, Dawber RP, Gatter K. Folliculitis decalvans including tufted folliculitis: clinical, histological and therapeutic findings. $\mathrm{Br} J$ Dermatol 1999;140:328-33.

6. Pujol RM, García-Patos V, Ravella-Mateu A, Casanova JM, de Moragas JM. Tufted hair folliculitis: a specific disease? Br J Dermatol 1994;130:259-60.

7. Jappe U, Schröder K, Zillikens D, Petzoldt D. Tufted hair folliculitis associated with pemphigus vulgaris. J Eur Acad Dermatol Venereol 2003;17:223-6.

8. Petronic-Rosic V, Krunic A, Mijuskovic M, Vesic S. Tufted hair folliculitis: a pattern of scarring alopecia? J Am Acad Dermatol 1999;41:112-4.

9. Fernandes JC, Correia TM, Azevedo F, Mesquita-Guimarães J. Tufted hair folliculitis after scalp injury. Cutis 2001;67:243-5.

10. Ekmekci TR, Koslu A. Tufted hair folliculitis causing skullcap-pattern cicatricial alopecia. J Eur Acad Dermatol Venereol 2006;20:227-9.

11. Isomura I, Morita A, Tamada Y. A case of tufted hair folliculitis. J Dermatol 2002;29:427-30.

12. Pranteda G, Grimaldi M, Palese E, Di Napoli A, Bottoni U. Tufted hair folliculitis: complete enduring response after treatment with rifampicin. J Dermatol Treat 2004; 15:396-8 